\title{
Comparison between existing and experimental surgical gowns for mass per unit area by using small samples
}

\author{
Farzana Kishwar ${ }^{1 *}$, Basit $\mathrm{Ali}^{2}$, Danial $\mathrm{Ali}^{3}$ and Mehreen $\mathrm{Ijaz}^{4}$ \\ 1. Govt. College of Women Bhaghbanpura, Lahore-Pakistan \\ 2. Mayo Hospital, Lahore-Pakistan \\ 3. Akhtar Saeed Medical and Dental College, Lahore-Pakistan \\ 4. Department of Home Economics, Lahore College for Women University-Pakistan \\ *Corresponding author's email: drfarzanakishwar@gmail.com \\ Citation
}

Farzana Kishwar, Basit Ali, Danial Ali and Mehreen Ijaz. Comparison between existing and experimental surgical gowns for mass per unit area by using small samples. Pure and Applied Biology. Vol. 9, Issue 3, pp2025-2032. http://dx.doi.org/10.19045/bspab.2020.90216

\begin{tabular}{llll}
\hline Received: 09/03/2020 & Revised: 30/05/2020 & Accepted: 02/06/2020 & Online First: 15/06/2020 \\
\hline \hline
\end{tabular}

\section{Abstract}

The selection of an appropriate material used for manufacturing medical textiles is an important subject for health care personnel in terms of providing safety and protection against many hazards at work place. The present study aimed at determining mass per unit area of various fabrics used for making surgical gowns. A comprehensive comparison was made between existing and experimental gowns. The study was experimental in nature. All laboratory work was performed at PCSIR Laboratories Complex Lahore. Samples of existing gowns were collected from public and private hospitals in Lahore. These were categorized into three groups A, B and C based on their fiber content. Experimental fabric was manufactured with $99 \%$ polyester and $1 \%$ carbon fiber by following plain interlacing pattern. Mass per unit area of existing and experimental fabrics for gowns was identified through BS EN 12127 test method at $0,5^{\text {th }}, 10^{\text {th }}, 15^{\text {th }}$ and $20^{\text {th }}$ laundering intervals. Results were tabulated and presented though graphs. Descriptive statistics along with statistical correlation was determined. P-value less $\leq 0.05$ was considered as significant. According to the results of mass per unit area, it was found that weight of existing surgical gown fabric increased after consequent launderings whereas experimental surgical gown weight remained the same.

Keywords: ASTM; Existing Surgical Gowns; Experimental surgical gowns; Laundering Intervals; Mass per Unit Area

\section{Introduction}

Textiles possess a unique potential to perform as an interface between the body and hostile environment. In the new generation of textiles, this potential of textiles is being utilized to provide the resistance not only against cold or rain but also against microorganisms and impact forces etc. A lot of research work, starting from wound care to tissue engineering is being done in the field of medical textiles. The increasing awareness about transmittable infections in the hospitals led the medical textiles to become an important component in the field of research and development for the betterment of personnel working in operation rooms. [13].

A growing fear of contact with different microbes \& their transmission through patients is increasing day by day among surgeons and operating staff. At present definite measures are required to decrease the threat of infections in operation theatre $[4,5]$. This has been worldwide confirmed and new guidelines have been announced by different societies. At present, surgical gowns and drapes are being used to defend 
healthcare professionals as well as the patients from microbes, transmitted by the medical staff and patient by themselves [68].

Various factors contribute to either usability or disposability of surgical gowns [9]. These are the dampness, the number of washings given, the environment in which the gown is kept, the sterilizations given, the span of surgical operations in which it is used, etc. [10, 11]. Fabrics used for surgical gown comprised of three ranges; one which completely resist the microbial penetration through all investigations whereas, the other resist for a specific time period, and the third one is completely penetrable [12]. Some parts of the surgical gowns suffer greater pressure and friction than other parts of the gown such as exerted by elbows or sleeves. As a result, the chances of infectivity at some areas of surgical gowns are more than the others. Therefore, some parts of surgical gown will stop the diffusion and other parts of it won't [13-15].

The potential of surgical gowns to prevent from contamination depends on the physical conditions i.e. their physical properties. Researchers found that there should be some specific characteristics in surgical gowns such as they have capacity to resist against scratch, tear, flame, liquid strike, bacterial strike and any kind of discharge [2]. Modern technology has successfully incorporated just some of these properties into surgical gowns. Therefore some characteristics have to be compromised upon to attain the more desirable ones but all is not done. Some properties did not incline to get along with each other whereas some of the features did so. Mass per unit area of any fabric depicts its weight in grams per meter square $\left(\mathrm{g} / \mathrm{m}^{2}\right)$. The current standard American Society for Testing and Materials for Mass per unit area is $98.5 \mathrm{~g} / \mathrm{m}^{2}$ (ASTM-D3776 Standard Test Methods for Mass per Unit Area). The literature shows that the heavier the weight, generally the thicker the fabric will be, although bear in mind that the weight does not tell you how thick the fabric is. Fabrics with different fibers or weaves but with the same weight may not have the exact same thickness [16]. The weight of a material does not always determine its quality. Different fabric weaves and yarns will have different weights, which is essential for its end use. Mass per unit area of textiles is also dependents on the type and material of the fabric used in manufacturing the surgical gown fabric [1, 17].

\section{Materials and methods}

The current study is being conducted to study the Mass per unit area of Existing and Experimental Surgical Gowns in private and Govt. hospitals of Lahore. The mass per unit area of a fabric is determined by weighing test specimens of known dimensions, cut from various locations over the full width of the laboratory sample [18]. The calculated values are then averaged to obtain the mean mass per unit area of the laboratory sample.

Five specimens from each of the selected hospitals were randomly collected to assess their mass per unit area after various laundering intervals. So, a total of fifteen specimens (existing samples) were taken and evaluated by following international test procedure. These samples were laundered with front loading machine at the speed of $38 \mathrm{C}^{0}$ temperature for three minutes in rinse cycle, for $60 \mathrm{C}^{0}$ in wash cycle for 7 minutes along with the standardized detergent. 2 minute spin cycle was again given at the temperature of $60 \mathrm{C}^{0}$ to remove any residual chemicals from the surface of fabrics. Then these were sterilized at $130 \mathrm{C}^{0}$ for 90 minutes. The existing samples were given 20 laundering cycles and evaluated after every five intervals. A new experimental sample was manufactured at Asher Textiles by following plain interlacing pattern and setting mass per unit area at $98.567 \mathrm{~g} / \mathrm{m}^{2}$. This experimental fabric was also laundered by following the same procedure used for existing samples for up to 20 washing cycles. A comparison was made between existing and experimental fabrics. 


\section{Determination of mass per unit area using small samples}

All the samples of surgical gowns were evaluated for mass per unit area following [17]. For this, fabrics were relaxed prior to testing. The fabrics were kept in a flat, tension free sate for $24 \mathrm{~h}$ during conditioning [19]. Then at least five test specimens of minimum $100 \mathrm{~cm}^{2}$ were cut out from each sample using the cutting device avoiding distortion of the fabric. The area of the cutting device was used for the calculation. Then each individual test specimen was weighed and recorded each value to the nearest $1 \mathrm{mg}$. The oven was preheated to $105 \pm 3{ }^{\circ} \mathrm{C}$. The test specimens were placed individually in weighing bottles and placed the bottles with the lid adjacent to them in the oven and dried to constant mass, which was considered as attained when no progressive change in mass greater than $0,1 \%$ occurs in successive weighing separated by a drying period of at least $40 \mathrm{~min}$. After drying, the lids were placed on the weighing bottles and cooled the bottles in a desiccator.

1. Each specimen was weighed in the bottle and the bottle alone, and recorded each value. The individual oven-dry mass of each test specimen was calculated. For each test specimen, the mass per unit area, $M$, in grams per square meter was calculated using the following formula:

$\mathrm{M}=\frac{\mathrm{m} \times 10000}{\mathrm{~A}}$

Where:

$\mathrm{m}$ is the mass of a test specimen, conditioned or oven-dry in grams;

$\mathrm{A}$ is the area of the same test specimen, in square centimeters.

The mean mass per unit area in grams per square meter was calculated and rounded the result to three significant figures [17].

\section{Results and discussion}

Results are tabulated and analyzed statistically through Statistical Package for Social Sciences (SPSS). Graphs are also made for comparison. Mass per unit area of any fabric depicts weight in grams per meter square $\left(\mathrm{g} / \mathrm{m}^{2}\right)$. The current standard for Mass per unit area ASTM is $98.5 \mathrm{~g} / \mathrm{m}^{2}$ (ASTM-D3776 Standard Test Methods for Mass per Unit Area) [1]. The statistical significance of this fabric using the mentioned above standard was evaluated. The literature shows that mass per unit area is also dependent on the type and material of the fabric used in surgical gowns. Cotton material is supposed to gain more weight during laundering as compared to Polyester I cotton blend. The surgical gowns subjected to Mass per unit area test, results are tabulated in (Table 1).

In above table mean mass per unit area for all samples of clothes is indicated from new gown to $20^{\text {th }}$ laundering in 5-laundering intervals. A total of 5 samples were chosen in each group labeled as Group A, B and C. The mean mass per unit area for group $\mathrm{A}$ for new gown was noted as $179.76 \pm 21.63$, $183.08 \pm 23.28$ at $5^{\text {th }} \quad$ Laundering, $186.90 \pm 24.37$ at $10^{\text {th }}$ Laundering, $191.80 \pm 25.08$ at $15^{\text {th }}$ Laundering and $194.52 \pm 23.48$ at $20^{\text {th }}$ Laundering. In Group $\mathrm{B}$, the average values for mass per unit area for these intervals was observed as 192.10 $\pm 41.69, \quad 205.60 \pm 45.46$, $210.16 \pm 48.07, \quad 217.86 \pm 48.92$ and $225.08 \pm 50.71$ respectively. Similarly, in Group C, the mean values for mass per unit area for these intervals were seen as $181.70 \pm 73.27$ 188.48 \pm 74.05 , $195.54 \pm 71.29, \quad 198.90 \pm 76.31 \quad$ and $200.42 \pm 78.81$ respectively.

Fig. 1 shows mass per unit area for all 3 groups at different laundering intervals. It can be clearly seen that mass per unit area in group-B was higher throughout as compared to group-A and C. According to p-value mean mass per unit area was statistically different in all three groups from new gown to $20^{\text {th }}$ laundering. ( $\mathrm{p}$-value $=0.039$ )

\section{Mass per unit area of experimental gowns}

Mass per unit area of any fabric depicts weight in grams per square meter $\left(\mathrm{g} / \mathrm{m}^{2}\right)$ (Fig. 2). The current standard of ASTM for Mass per unit area is $98.5 \mathrm{~g} / \mathrm{m}^{2}$ (ASTMD3776) [1]. The experimental fabric has 
been prepared according to the ASTM standard weighing $98.5 \mathrm{~g} / \mathrm{m}^{2}$. The surgical gowns in phase- II subjected to Mass per unit area test and results are tabulated in (Table 2, Fig. 3)

The mass per unit area in new gown was $98.567 \mathrm{~g} / \mathrm{m}^{2}$, at $5^{\text {th }}$ laundering the mass per unit area was $98.753 \mathrm{~g} / \mathrm{m}^{2}$, at $10^{\text {th }}$ laundering mass per unit area $98.853 \mathrm{~g} / \mathrm{m}^{2}$, at $15^{\text {th }}$ laundering mass per unit area $98.839 \mathrm{~g} / \mathrm{m}^{2}$ and at $20^{\text {th }}$ laundering mass per unit area was $98.892 \mathrm{~g} / \mathrm{m}^{2}$. In (Fig. 4) a clear increasing trend can be seen. New gown fabric weight was $98.567 \mathrm{~g} / \mathrm{m}^{2}$ and at $20^{\text {th }}$ washing it increased to $98.892 \mathrm{~g} / \mathrm{m}^{2}$. There is no significant difference in weight of surgical gown fabric from new to $20^{\text {th }}$ laundering.

Table 1. Descriptive Statistics for Mass per unit area using small samples at different laundering intervals

\begin{tabular}{|c|c|c|c|c|}
\hline & \multirow{2}{*}{$\begin{array}{c}\text { Groups } \\
\text { Groups }\end{array}$} & \multirow{2}{*}{$\begin{array}{l}\mathbf{N} \\
\mathrm{N}\end{array}$} & \multicolumn{2}{|c|}{$\begin{array}{l}\text { Mass per unit area } \\
\left(\mathrm{g} / \mathrm{m}^{2}\right)\end{array}$} \\
\hline & & & Mean & SD \\
\hline \multirow{3}{*}{$\begin{array}{l}\text { Mass per Unit Area using Small Samples } \\
\text { (New Gown) }\end{array}$} & Group-A & 5 & 179.76 & 21.63 \\
\hline & Group-B & 5 & 192.10 & 41.69 \\
\hline & Group-C & 5 & 181.70 & 73.27 \\
\hline \multicolumn{2}{|l|}{ Total } & 15 & 184.52 & 46.86 \\
\hline \multirow{3}{*}{$\begin{array}{l}\text { Mass per Unit Area using Small Samples (05- } \\
\text { laundering) }\end{array}$} & Group-A & 5 & 183.08 & 23.28 \\
\hline & Group-B & 5 & 205.60 & 45.46 \\
\hline & Group-C & 5 & 188.48 & 74.05 \\
\hline \multicolumn{2}{|l|}{ Total } & 15 & 192.38 & 49.10 \\
\hline \multirow{3}{*}{$\begin{array}{c}\text { Mass per Unit Area using Small Samples (10- } \\
\text { laundering) }\end{array}$} & Group-A & 5 & 186.90 & 24.37 \\
\hline & Group-B & 5 & 210.16 & 48.07 \\
\hline & Group-C & 5 & 195.54 & 71.29 \\
\hline \multicolumn{2}{|l|}{ Total } & 15 & 197.53 & 48.79 \\
\hline \multirow{3}{*}{$\begin{array}{c}\text { Mass per Unit Area using Small Samples (15- } \\
\text { laundering) }\end{array}$} & Group-A & 5 & 191.80 & 25.08 \\
\hline & Group-B & 5 & 217.86 & 48.92 \\
\hline & Group-C & 5 & 198.90 & 76.31 \\
\hline \multicolumn{2}{|l|}{ Total } & 15 & 202.85 & 51.54 \\
\hline \multirow{3}{*}{$\begin{array}{c}\text { Mass per Unit Area using Small Samples (20- } \\
\text { laundering) }\end{array}$} & Group-A & 5 & 194.52 & 23.48 \\
\hline & Group-B & 5 & 225.08 & 50.71 \\
\hline & Group-C & 5 & 200.42 & 78.81 \\
\hline \multicolumn{2}{|l|}{ Total } & 15 & 206.67 & 53.43 \\
\hline
\end{tabular}

Factor $(\mathrm{p}$-value $)=0.000$ (Significant: $\mathrm{p}$-value $<0.05)$

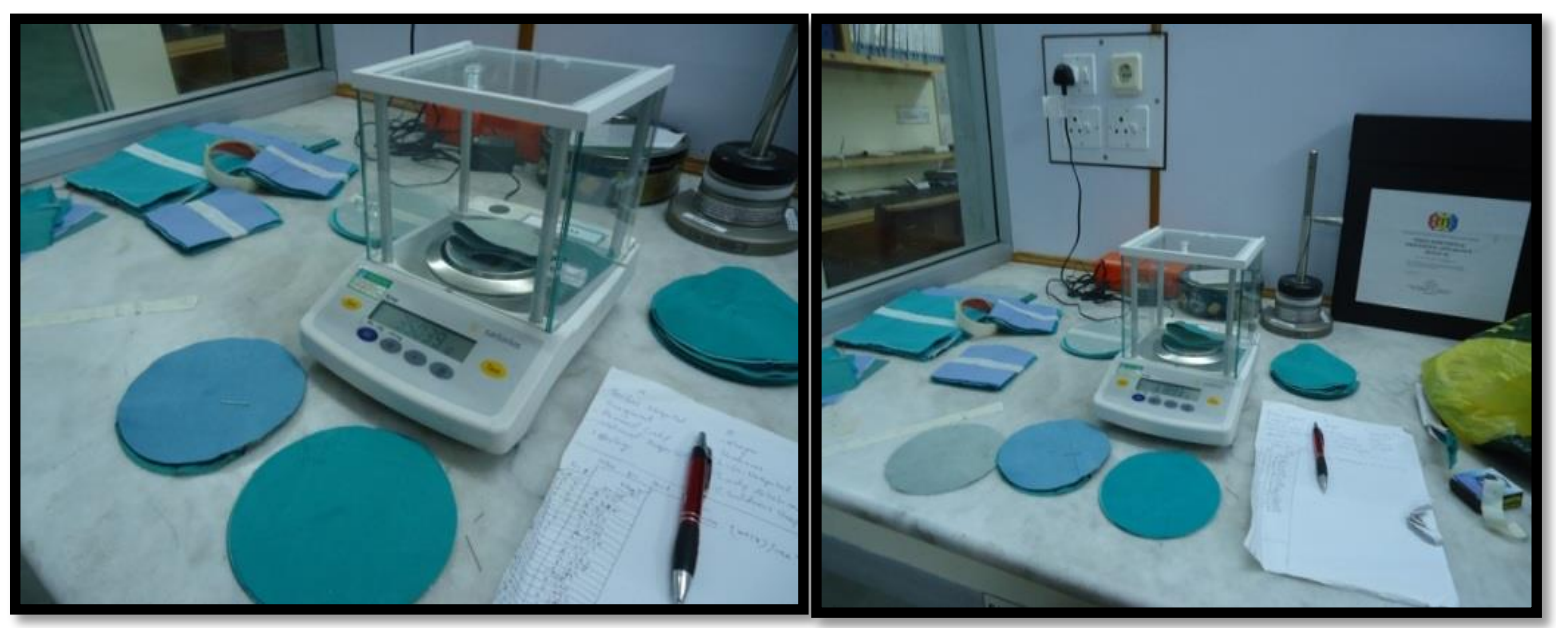

Figure 1. Determination of mass per unit area by using small samples 


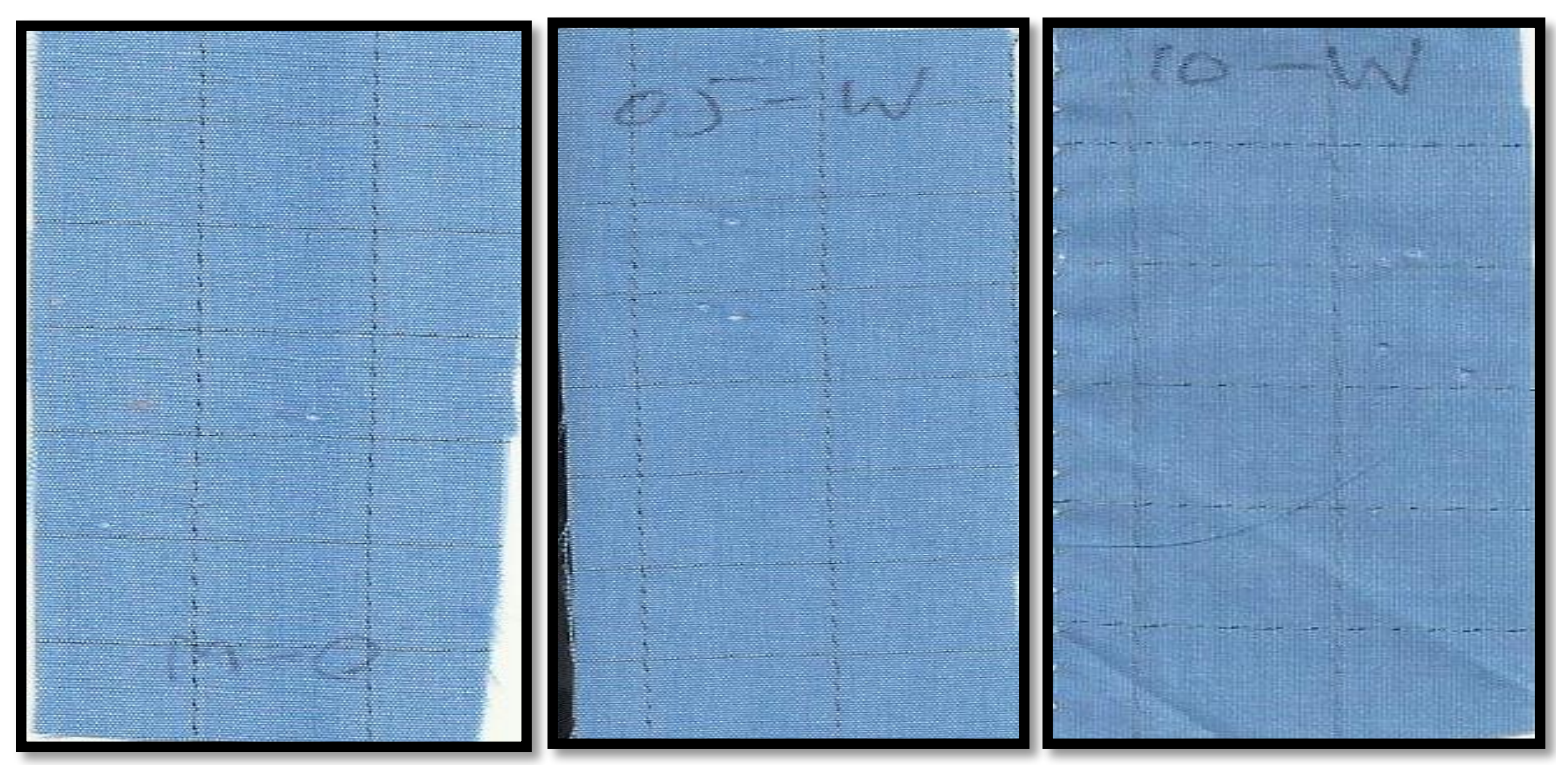

Figure 2. Samples of experimental surgical gowns

Table 2. Determination of mass per unit area using small samples

\begin{tabular}{|c|c|c|c|c|c|c|}
\hline $\begin{array}{c}\text { S. } \\
\text { Code }\end{array}$ & & $\begin{array}{c}\text { Mass per } \\
\text { Unit Area } \\
\left(\mathbf{g} / \mathbf{m}^{\mathbf{2}}\right) \\
\mathbf{N e w} \mathbf{g o w n}\end{array}$ & $\begin{array}{c}\text { Mass per } \\
\text { Unit Area } \\
\left(\mathbf{g} / \mathbf{m}^{2}\right) \\
\mathbf{5 - L}\end{array}$ & $\begin{array}{c}\text { Mass per } \\
\text { Unit Area } \\
\left(\mathbf{g} / \mathbf{m}^{2}\right) \\
\mathbf{1 0 - L}\end{array}$ & $\begin{array}{c}\text { Mass per } \\
\text { Unit Area } \\
\left(\mathbf{g} / \mathbf{m}^{\mathbf{2}}\right) \\
\mathbf{1 5}-\mathbf{L}\end{array}$ & $\begin{array}{c}\text { Mass per Unit } \\
\text { Area }\left(\mathbf{g} / \mathbf{m}^{\mathbf{2}}\right) \\
\mathbf{2 0 - L}\end{array}$ \\
\hline AT & $\begin{array}{c}\text { Ashar } \\
\text { textiles }\end{array}$ & $98.567 \mathrm{~g} / \mathrm{m}^{2}$ & $98.753 \mathrm{~g} / \mathrm{m}^{2}$ & $98.853 \mathrm{~g} / \mathrm{m}^{2}$ & $98.839 \mathrm{~g} / \mathrm{m}^{2}$ & $98.892 \mathrm{~g} / \mathrm{m}^{2}$ \\
\hline
\end{tabular}

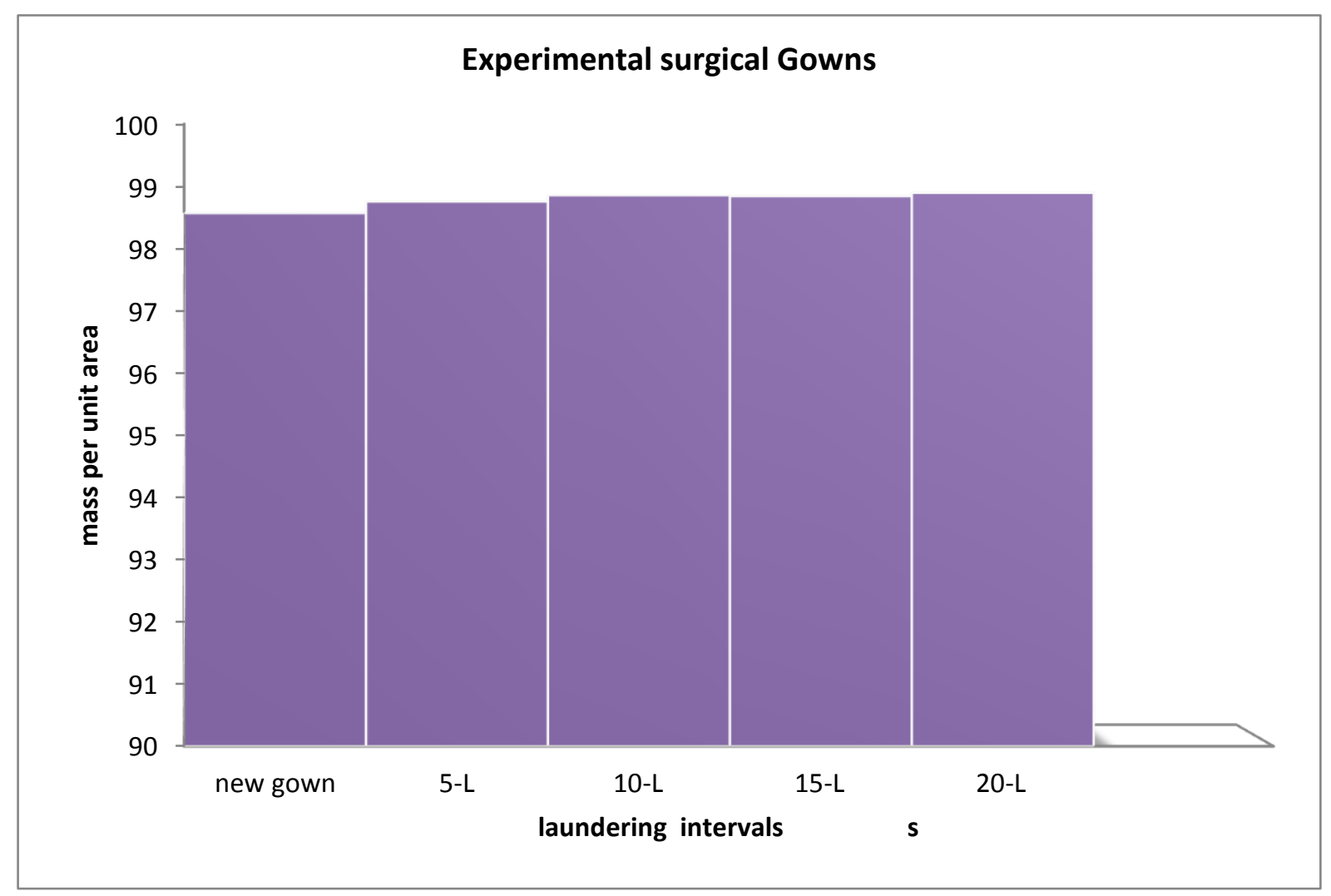

Figure 3. Mass per unit area using small samples at different laundering intervals 


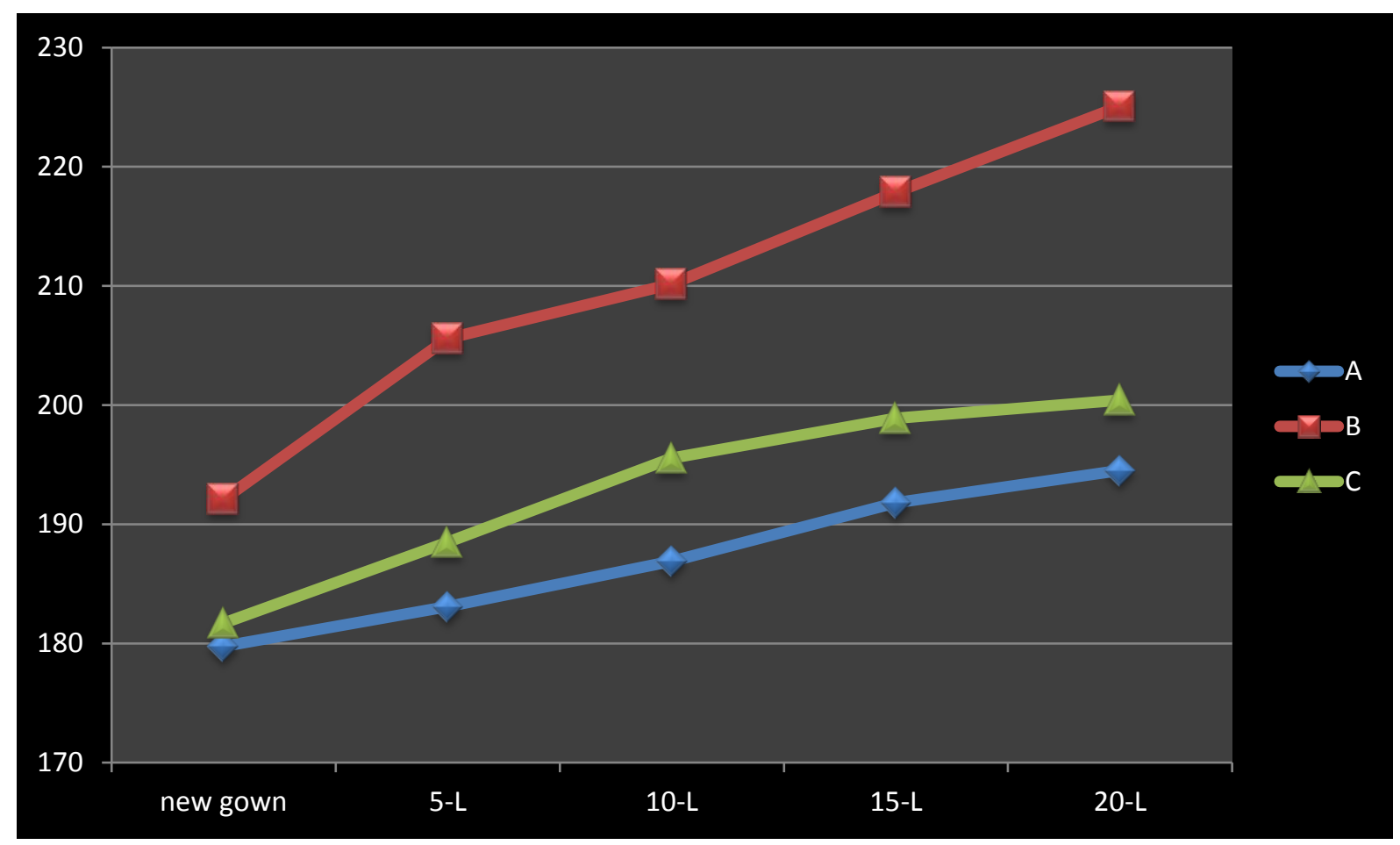

Figure 4. Factor $*$ Group $(p-v a l u e)=0.039($ Significant: $p$-value $<0.05)$

The overall mean mass per unit area (collective of all groups) also showed an increasing trend with increasing number of laundries. Hence it is evident from this table that the mass per unit area showed an increasing trend in all samples when measured at increasing laundering intervals. The fact was also supported by significant results, which showed that, mean mass per unit area was statistically different in different laundry groups i.e. (pvalue $=0.000$ )

There are various reasons for increase in mass of the fabric which includes gain in moisture, accretion of the various impurities imbibed during washing like chemicals from detergents, \& dust particles, etc. Prior to World War II (1940), soaps were used in laundering [20]. Soaps are made up of fats or fatty acids, and some fat residue left on the laundered fabrics. The increased weight of fabric is due to the deposition of detergent and impurities on fabric [21]. After World War II, the synthetic detergents were developed and used frequently as laundry products, accompanying the advent of modern washing machines and automatic dryers [22]. The synthetic detergents were more powerful cleaning clothes than soaps and left no residue on the fabrics whereas in Pakistan we are still using soaps and harsh detergents [23]. However, the harsh mechanical agitation of the washing machine distorted surface fibers and created entanglement, leaving the fabric with a stiff and uncomfortable hand [24, 25]. In addition, the machine laundering left fabrics with an uncomfortable hand as a result of the removal of the fatty finish and lubricating waxes on the fabric when the synthetic detergents removed dirt and oil. As a result, after the introduction of synthetic detergents to the market, the need for a fabric softener was recognized. Fabric softeners were introduced to the United States market in the early 1950sto modify the hand and to restore lost physical properties of laundered clothes [26, 27]. In 1950 fabric softeners were introduced in United States but in Pakistan surgical gowns are still being washed with soap and there is no fabric softener. A very bad odor 
of soap (fat) is still there even after sterilization.

The literature shows that mass per unit area is also dependent on the type and material of the fabric used in surgical gowns. As cotton fabric is supposed to gain more weight during laundering as compared to Polyester. Polyester is a hydrophobic fiber, which means that it is non-polar and, therefore, does not attract water. Because of this reason experimented surgical gown is made of $99 \%$ polyester fiber. There are various reasons for increase in mass of the fabric. Besides soil removal, the inversed process, i. e. re deposition, is actual and appears particularly in heavily soiled washing liquors as a consequence, white fabrics turn grey [17]. The laundering and sterilization procedure was the same for experimented gowns as was for existing gowns. So the increase in weight is for the above stated reason. In existing gown group for all categories of hospitals the lightest gown was $101.8 \mathrm{~g} / \mathrm{m}^{2}(\mathrm{C}-5)$ and the heaviest one was $293.0 \mathrm{~g} / \mathrm{m}^{2}$ whereas the experimental surgical gown weighed $98.567 \mathrm{~g} / \mathrm{m}^{2}$, which is according to the ASTM standard [1].

\section{Conclusion}

The factor under consideration in this study was mass per unit area (using small samples) of existing \& experimental surgical gowns. The results were compared between Existing And Experimental Surgical Gown for results of Mass Per Unit Area (using small samples). The surgical gowns were collected from fifteen different hospitals under study. These surgical gowns were subjected to Mass Per Unit Area (using small samples) to check the Mass per unit area of the fabric at different laundering intervals. The results indicated that the fabric used for the existing surgical gowns was lightweight and some cases it was heavy. But for experimental surgical gowns fabric mass per unit area was according to the given standard whereas existing surgical gowns did not match any international standard or parameter either. Among three groups under study for existing surgical gowns none of the group showed ratings near standard but experimental surgical gowns were according to standard.

\section{Authors' contributions}

Conceived and designed the experiments: $\mathrm{F}$ Kishwar, Performed the experiments: $F$ Kishwar \& M Ijaz, Analyzed the data:F Kishwar, M Ijaz \& D Ali, Contributed materials/ analysis/ tools: B Ali \& M Ijaz, Wrote the paper: F Kishwar, D Ali \& B Ali.

\section{References}

1. ASTM International (2012).

Recommended Standards of Practice for Surgical Drapes. West Conshohocken, PA: ASTM International.

2. Association for the Advancement of Medical Instrumentation (2015). Selection and use of protective apparel and surgical drapes in health care facilities. Technical Information Report: TIR11: 2005-2015.

3. ASTM International (2012). Recommended Standards of Practice for Surgical Drapes. West Conshohocken, PA: ASTM International. Retrieved from http://www.ast.org/pdf/Standards_of_ Practice/RSOP_Surgical_Drapes.pdf

4. Coughlin M (1999). Effect of laundering on the barrier properties of reusable surgical gown fabrics. AORN J 3(4): 73-82.

5. Sabesan S (2005). Patent No. 7,629,000. Washington, DC: U.S. Patent and Trademark Office.

6. ASTM. (2012). Recommended Standards of Practice for Surgical Drapes. West Conshohocken, PA: ASTM International.

7. Batra S (1992). Medical and surgical disposibles protect healthcare workers and patient. In 3rd (Ed.), The Nonwoven Fabrics Handbook India. pp 19-22

8. Laufman H, Eudy WW,Vandernoot AM, Harris CA \& Liu D. (1975). Strike-through of moist contamination 
by woven and non-woven surgical material. Ann Surg, 181(6): 857-862.

9. Jinkins RS \& Leonas KK (1995). Influence of a polyethylene glycol treatment on surface,liquid barrier and antibacterial properties. Textile Chem Color 26(12): 25-29.

10. Kishwar F, Kalsoom S, Khan F \& Alam S (2011). Surgical apparels: comparison of some physical parameters. Prof Med J 18(3): 390395.

11. Quebbeman EJ, Telford GL, Hubbard S, Wadsworth K, Hardman B \& Goodman H (1992). In- use evaluation of surgical gowns. Surg Gynecol Obstet, 174(5): 369-375.

12. McCall D, Stock D. \& Achey, $P$ (2001). Intro to Microbiol Malden, MA: Blackwell Sci pp 65-87.

13. Jones A (2008). Bare below the elbows:A brief histoery of surgeon attire and infection. BJU Int 102(6): 665-666.

14. Kadloph SJ \& Langfold AJ (1998). Textiles (8th ed.). Prentice- Hall.

15. Shaw LH. (1998). Cotton's importance in the textile industry. Lima, Peru, pp 37-59

16. Umbach KH. (2006). Physiological function of OR- and hospital protective clothing. FiberMed06. Finnland. pp 16-39.

17. BS EN 12127. (1997). TextileFabrics,Determination of mass per unit area using small samples. British Standards Institution. Retrieved from https://shop.bsigroup.com/ProductDet ail?pid=000000000001281884

18. Vigo TL (1978). Modified cellulosics. New York: Academic Press.

19. ISO 7211-2 (2012). Textile-woven fabrics-construction-methods of analysis. Determination of number of threads per unit length. International Organization for Standardization Retrieved

fromhttp://www.iso.org/iso/iso_catalo gue/catalogue_tc/catalogue_detail.htm ?csnumber $=13842$

20. ISO139 (2005). Textiles-standard atmosphere for conditioning and testing. International Organization for Standardization. Retrieved from https://www.iso.org/standard/35179.ht $\mathrm{ml}$

21. Kishwar F, Khan F \& Alam S (2011). A study to assess the prevailingperformance specifications for surgical gowns and scrubs. Ann Pak Inst Med Sci 7(2): 104-108.

22. Raheel M (1994). Protective clothing systems and materials. New York: Marcel Dekker, Inc. pp 1-23

23. Dusaj S (1993). Making composite barrier fabrics for healthcare workers. Tech Tex Int 1(2): 20-22.

24. Putcha R (1984). Cationic surfactants in laundry detergents and laundry after treatment aids. J Amer Oil Chem Soc 61(2): 367-376.

25. Yen MS, Chen JC \& Hong CC (2006). Pore structures and antibacterial properties of cotton fabrics treated with DMDHEU-AA by plasma processes. Text Res J 4(1): 208-215.

26. Technical Information Report (1994). Selection of Surgical Gowns and Drapes in Health Care Facilities. Arlington, VA: Association for the Advancement of Medical Instrumentation 1: 3-17.

27. Xie S (2002). Characterization of interyarn pore size and its distribution in plain woven fabrics. Master Thesis. North Carolina State University, Raleigh. 